\title{
Was Wittgenstein a Conservative Philosopher?
}

Robert Vinten é doutorando em Filosofia pela Universidade Nova de Lisboa.

\begin{abstract}
J. C. Nyiri has argued in a series of papers that Ludwig Wittgenstein is a conservative philosopher. In 'Wittgenstein 1929-31: The Turning Back' Nyiri cites Wittgenstein's admiration for Grillparzer as well as overtly philosophical passages from On Certainty in support of that thesis. I argue, in opposition to Nyiri, that we should separate Wittgenstein's political remarks from his philosophical remarks and that nothing Wittgenstein says in his philosophical work obviously implies a conservative viewpoint, or any other kind of political viewpoint. In his philosophical work Wittgenstein was concerned with untangling conceptual confusions rather than with putting forward a political viewpoint and the two kinds of activities are quite different. There is, however, some evidence of elements of conservatism in the stances that Wittgenstein took on political issues although there is also some evidence of sympathy for left-wing views, particularly during the 'late' period of Wittgenstein's work after he returned to philosophy at the end of the 1920s. Wittgenstein's philosophical work cannot be claimed by people of any particular political persuasion as their own but it can be used to untangle philosophical problems in the work of a great variety of political philosophies.
\end{abstract}

\section{Key Words}

Wittgenstein; Conservatism

\section{I - Introduction}

$\mathrm{T}$ he question of whether Wittgenstein was a conservative philosopher has generated a large literature[1]. Given the enormous scope of the literature there will not be space here to consider all of the various arguments in favour of deeming Wittgenstein a conservative. In particular many have focussed in on Wittgenstein's claim in $\S 124$ of the Philosophical Investigations that philosophy "leaves everything as it is". That remark alone is deserving of a paper to itself and if controversies surrounding Wittgenstein's remarks about rule-following, rationality, and relativism were taken into consideration a sizable book could be written on the topic. I will restrict myself here to the arguments found in J. C. Nyiri's paper 'Wittgenstein 1929-31: The Turning Back'.

The evidence brought by each side of the debate about whether Wittgenstein was conservative can be roughly divided into evidence concerning Wittgenstein's occasional remarks directly concerning political matters and evidence from amongst Wittgenstein's philosophical remarks. The reason I say 'roughly' divided is that there is some controversy about the extent to which this division can be made. Within Wittgenstein's typescripts each kind of remark would not be clearly separated; a remark about politics might be followed by a remark about philosophy, and philosophers might think that 
there is no clear division between the two kinds of remark (or that there aren't two kinds of remark at all). In this paper I will treat the political remarks and philosophical remarks separately and I hope that by the end of the paper it will become clearer how a separation can be made. I will argue that philosophical remarks that have been construed as having political implications do not in fact have the implications that some commentators have suggested.

If we can separate out the two kinds of remark then there are really two questions to answer. Firstly we can ask whether Wittgenstein was conservative in his political views and secondly we can ask whether Wittgenstein's philosophical remarks have conservative political implications. To the first question my answer will be that Wittgenstein certainly held some political views that can be deemed conservative (although he also held some views that could be characterized as left-wing). But my answer to the second question will be that Wittgenstein's philosophical views are perfectly consistent with radical left-wing views and have no conservative implications. Before looking at the evidence that Wittgenstein held conservative political views we must first have some understanding of what conservatism is.

\section{II - What is conservatism?}

One thing worth getting clear about when discussing conservatism is that the members of conservative parties are not necessarily conservative in their philosophical outlook and even if they are conservative they may well disagree on many questions. Rightwing liberals have allied themselves with conservatives against the common enemy of socialism. As Anthony Quinton notes in his account of conservatism, “...conservative parties have absorbed so many right-wing liberals...that at times the truly conservative element in them has been almost overwhelmed by liberal individualism"[2]. This alliance of liberal individualism and conservatism can be seen in one of the most prominent Conservative Prime Ministers of the past few decades, Margaret Thatcher. She led the Conservative Party in Britain between 1975 and 1990 (she was Prime Minister from 1979-1990) and she was a great admirer of the right-wing liberal individualist Friedrich Hayek. Hayek himself explicitly disassociated himself from conservatism in his book The Constitution of Liberty, to which he appended a postscript, entitled 'Why I am not a conservative'[3]. The stress on liberty, and especially a stress on the importance of free markets, is characteristic of right-wing liberalism rather than conservatism[4], although the two are often found in combination nowadays.

In the entry on conservatism in A Companion to Contemporary Political Philosophy Quinton identifies three central doctrines of conservatism: traditionalism, scepticism (concerning political knowledge) and the conception of human beings and society as being organically related[5]. According to conservatives societies are like biological organisms in that the parts (organs) all play their role in the functioning of the whole and cannot flourish independently of the whole. Each organ has its place and its role and each organ depends on the whole in order to play that role. Similarly, in societies individuals have their proper place and their proper roles to fulfil and they cannot flourish except by being part of a wider whole, their society. This organicism supports sceptical claims about political knowledge. Individuals are imperfect in that they cannot flourish independently of society. No individual can grasp the whole and so theories formulated by individuals will inevitably be imperfect. Radically altering one aspect of society will have ramifying effects throughout all of society and so drastic change is to be avoided because it will have unpredictable results. Society is enormously complex 
and interrelated. Any changes made should be gradual and should respect the wisdom that has accumulated in long-standing traditional institutions. According to conservatives traditional institutions should be maintained (conserved) and if change is felt to be necessary we should proceed cautiously, remembering that drastic change could have drastic negative effects elsewhere in society.

In his article 'Wittgenstein 1929-31: The Turning Back' J. C. Nyiri relies upon a characterisation of conservatism that is closely related to the one given above that was presented by Klaus Epstein in his book The Genesis of German Conservatism[6]. The organicism, deemed by Quinton to be a central doctrine of conservatism, can be seen in Epstein's claim that conservatives, "...tend to emphasize the importance of variety whereas their opponents stress general norms". This supports scepticism about political knowledge (Quinton's second central doctrine of conservatism) in that individuals are unlikely to be able to grasp the whole through norms or generalisations because there is such a great variety of people in a great variety of roles. This means that "...the systematic application of reason to political, economic and religious problems usually leads to disastrous results" and supports the third strand of conservatism identified by Quinton, traditionalism. So all of the strands identified by Quinton are present in the account of conservatism that Nyiri relies upon in his article discussing Wittgenstein's politics.

However, some social theorists have claimed that characterizations of conservatism like those given above are not sufficient. After all, the belief that change should be gradual and a belief in the interrelatedness (and variety) of people is just as compatible with reformist socialism as it is with those more usually associated with conservatism. George Nash, the author of a classic work on conservatism, notes that "[e]ven Fabian Socialists who believed in 'the inevitability of gradualness' might be labelled conservatives"[7] and Corey Robin, in his recent book about conservatism, The Reactionary Mind: Conservatism from Edmund Burke to Sarah Palin, takes this as a sign that more needs to be said in order to correctly characterize conservatism. Robin suggests that conservatism is "...a meditation on - and theoretical rendition of - the felt experience of having power, seeing it threatened, and trying to win it back". He argues, plausibly, that conservatives do not actually protect long-standing institutions unless those institutions fit with the interests of those in power. So conservatives defend the family and the nation but they do not view trade unions as valuable defenders of the rights of workers, despite the fact that trade unions have evolved and survived for many years. This fits with the fact that prominent conservative writers have often written in response to revolutionary movements or movements of oppressed groups. For example, Edmund Burke, the paradigmatic conservative philosopher, wrote in response to the French revolution and Salisbury, the Conservative prime minister wrote that "hostility to Radicalism, incessant, implacable hostility, is the essential definition of Conservatism. The fear that the Radicals may triumph is the only final cause that the Conservative Party can plead for its own existence"[9]. This leads Robin to claim that conservatism can be partially defined as "opposition to the liberation of men and women from the fetters of their superiors, particularly in the private sphere". So, to conclude this section, we can see conservatism as a combination of organicism (with regard to the relation between individual and society), scepticism (about knowledge of society and of politics), traditionalism, and the defence of power.

\section{III - Wittgenstein's Politics}


Revista Estudos Hum(e)anos

ISSN 2177-1006

Número 8, 2014/1

\section{(i) Evidence that Wittgenstein held conservative views}

\section{Wittgenstein's attitudes towards women}

One area of politics in which it seems quite clear that Wittgenstein held conservative views is the area of women's rights. There is evidence from a number of sources over the course of many years which tell us that Wittgenstein held sexist views. For example, David Pinsent, a close friend of Wittgenstein's, records in his diary on February 7th, 1913 that "[w]e talked about Woman suffrage: he [Wittgenstein] is very much against it - for no particular reason except that 'all the women he knows are such idiots'. He said that at Manchester University the girl students spend all their time flirting with the professors. Which disgusts him very much - as he dislikes half measures of all sorts, and disapproves of anything not deadly in earnest.'[11]

Evidence from other sources suggests that Wittgenstein continued to hold sexist views. Fania Pascal attended meetings of the Moral Science Club at Cambridge where Wittgenstein spoke (in 1930-31) and then later gave Wittgenstein lessons in Russian (in the mid-1930s) and became a personal friend of his. She claims that Wittgenstein "disliked intellectual women and in company literally turned his back on them"[12]. This is corroborated by the physicist Freeman Dyson, who lived nearby to Wittgenstein and had some interaction with him. Dyson claims that "he was, of course, always extremely insulting to women. He couldn't tolerate women coming to his lectures. He would just simply be so rude that they would have to leave. So a thoroughly disagreeable character."[13] Pascal explicitly describes Wittgenstein as conservative in the early 1930s. She claims that, "at a time when intellectual Cambridge was turning Left he was still an oldtime conservative of the late Austro-Hungarian Empire."[14]

There is some suggestion that Wittgenstein was not quite as extreme in his sexism as Dyson suggests. We know that Wittgenstein's lectures were attended by, amongst others, Margaret Masterman, Alice Ambrose, Elizabeth Anscombe, Iris Murdoch, and Margaret Macdonald. Masterman and Ambrose were members of the select group of students that made the notes which form Wittgenstein's Blue Book, and Ray Monk, one of Wittgenstein's biographers, describes them as being amongst Wittgenstein's favourite students[15]. Elizabeth Anscombe became a close friend of Wittgenstein's, and later translated his Philosophical Investigations, but it seems she was one of a few exceptions to Wittgenstein's general dislike of academic women. According to Ray Monk Anscombe became an 'honorary male', "addressed affectionately by him as 'old man"". Monk relates a story of Wittgenstein saying to Anscombe, "“[t]hank God we've got rid of the women!'" at a lecture when he found that there were no other female students left in attendance.[16]

So it is fairly clear that Wittgenstein was sexist but what makes this attitude a conservative one? In the first place it is a defence of the status quo, and a defence of the way that things have traditionally been. Women did not have the right to vote in Britain in 1913, when Wittgenstein announced his opposition to women's suffrage. There is also a kind of organicism in the idea that women should play a different role in society to men and Wittgenstein's attitudes accord with Corey Robin's claim that conservatism involves "opposition to the liberation of men and women from the fetters of their superiors, particularly in the private sphere." So it is safe to conclude that Wittgenstein was conservative in at least one respect; in terms of his attitudes towards women.

\section{Hostility to Marxism}


There is further evidence of Wittgenstein's conservatism, or at least hostility to leftwing views, in what people who knew him recount of what he said about Marxism. Wittgenstein had some acquaintance with the works of Marx and Lenin and his opinion of their works was in some respects quite low. Rush Rhees reports that Wittgenstein "used to speak with disgust of Marx's phrase "congealed labour time"" and that "he could imagine that many people would find Marx an infuriating writer to read"[17] and according to M. O'C. Drury Wittgenstein said that "Lenin's writings about philosophy are of course absurd"'[18]. When Rush Rhees said to Wittgenstein that he was thinking of joining the Revolutionary Communist Party Wittgenstein tried to dissuade him from doing so on the basis that as a philosopher you should always be prepared to change direction and being loyal to a party would not allow you the necessary flexibility to change course.

Of course, opposition to organised Marxism is not sufficient to label somebody a conservative but it is true, at least, that conservatives would share Wittgenstein's hostility to organised Marxism. However, there is some unclarity about the extent to which Wittgenstein really did oppose Marxism and that will be discussed later, in section III (ii).

\section{Wittgenstein's admiration of conservative thinkers}

In his article 'The Turning Back'[19] J. C. Nyiri argues that one thing to be said in favour of the thesis that Wittgenstein was conservative is that he admired Grillparzer and Grillparzer was a conservative thinker (as well as being a famous poet). In fact Wittgenstein's grandmother on his father's side of the family, Fanny Figdor, was personally acquainted with Grillparzer[20]. Nyiri notes that Wittgenstein made reference to Grillparzer in his notebooks on three occasions between 1929 and 1931. In the first note Wittgenstein talks about Grillparzer as a 'good Austrian'. Wittgenstein says that '[ $\mathrm{t}] \mathrm{he}$ good Austrian (Grillparzer, Lenau, Bruckner, Labor) is especially difficult to understand"'[21]. In the second note Wittgenstein quotes Grillparzer as saying: "How easy it is to move about in broad distant regions, how hard to grasp what is individual \& near at hand...'[22] Nyiri suggests that the distinction here, between 'broad distant regions' and 'what is individual \& near at hand' corresponds to the distinction between "concrete use of language and speculative chatter" [23] that conservatives want to make. According to Nyiri "[t]he conservative individual, with his preference for the concrete, for that which is given, is in fact always hostile to theory [i.e. 'speculative chatter']'[24]. In the third remark Wittgenstein says that '[i]n Bruckner's music nothing is left of the long \& slender (nordic?) face of Nestroy, Grillparzer, Haydn, etc. but it has in full measure a round full (alpine?) face even purer in type than was Schubert's". It is difficult to see how this third remark can be construed as suggestive of conservatism in Wittgenstein's thought, indeed it is difficult to make sense of at all. Nyiri suggests that in order to understand the remark we must place it in the context of the other remarks nearby. In particular, immediately after this remark Wittgenstein said that, "[ $t]$ he power of language to make everything look the same which appears in its crassest form in the dictionary \& which makes it possible to personify time, something which is no less remarkable than would have been making divinities of the logical constants". Nyiri claims that the context of the remark suggests that what connects the remark with those surrounding it is "the idea of original multiplicity, of diversity"[25] and emphasis on diversity is characteristic of conservatism. Nyiri cites Klaus Epstein's definition of conservatism in support of his view. Epstein suggests that "[c]onservatives...tend to emphasize the importance of variety, whereas their opponents stress general norms"[26]. 
Moreover, Nyiri does not just cite instances where Wittgenstein mentions or quotes Grillparzer. He proposes that conservative remarks are present in Wittgenstein's more overtly philosophical work. Examples of such remarks, Nyiri says, include some that have been published in On Certainty. According to Nyiri's interpretation, Wittgenstein maintains that we must "recognise certain authorities in order to be able to make judgements at all'"[27] (OC, §493). Nyiri claims, on the basis of $\S \S 47,644$ and 94 in On Certainty, that the authorities Wittgenstein thinks we must respect include "one's school, or an inherited picture of the world"[28]. This kind of respect for inherited institutions fits with the traditionalism of conservatism mentioned above and could perhaps also be seen as a defence of those in power.

\section{(ii) - Evidence which suggests that Wittgenstein was not conservative}

In this section of the paper I intend to present evidence that Wittgenstein was not wholly conservative in his political opinions. The analysis presented by Nyiri is largely philosophical in nature and so I will respond to that in section IV below.

\section{Wittgenstein's admiration of left-wing thinkers}

It is clear that Wittgenstein saw something in Grillparzer's views and that Grillparzer was a conservative. I will argue in section IV that what Wittgenstein gleaned from Grillparzer was more philosophical than political in nature and that Wittgenstein's philosophical views do not imply a conservative political philosophy. However, as has been noted many times already[29], Wittgenstein also admired thinkers on the left. His friends included people like Nikolai Bakhtin, described by Fania Pascal as "a fiery communist"[30], George Thomson; a Marxist classics lecturer at Birmingham who had a role in shifting Bakhtin's politics to the left, and Pierro Sraffa, an economist who was friends with the Marxist Antonio Gramsci and who Wittgenstein credits as being the stimulus for 'the most fruitful ideas' of the Philosophical Investigations[31]. Wittgenstein was also was friends with the communist writer and activist, Maurice Dobb, and shared lodgings with him for a while[32].

But there is not just evidence that Wittgenstein was friends with many people on the left, there is also evidence that Wittgenstein had some sympathy for their views. Although Wittgenstein said that he saw Lenin's philosophical views as absurd he followed this by saying "at least he did want to get something done"[33] and although Wittgenstein disliked Marx's way of expressing himself, Rush Rhees says that this did not mean that Wittgenstein objected to Marx's views[34]. It is worth noting that Wittgenstein, on more than one occasion, expressed a desire to visit communist Russia, first in 1922[35] (soon after the Russian Revolution) and then in 1935, when he did in fact go to Russia[36]. Some have argued that his interest in Russia had nothing to do with left-wing sympathies and more to do with his asceticism or even his (alleged) conservatism. For example, Fania Pascal said that " $[\mathrm{t}] \mathrm{o}$ my mind, his feeling for Russia would have had at all times more to do with Tolstoy's moral teachings, with Dostoevsky's spiritual insights, than with any political or social matters"[37].

However, there is evidence that there was more to Wittgenstein's motivations than this. In a letter of introduction that J. M. Keynes wrote to Ivan Maisky, the Russian ambassador in London, on behalf of Wittgenstein Keynes said that Wittgenstein "has strong sympathies with the way of life which he believes the new regime in Russia stands for" [38]. What did Wittgenstein believe the regime in Russia stood for? According to Rush Rhees "Wittgenstein would say [towards the end of the Second World War] 'the 
important thing is that the people have work'...He thought the new regime in Russia did provide work for the mass of the people...He also thought it would be terrible if the society were ridden by 'class distinctions"'[39]. In a footnote Rhees adds "[w]hen I said that the 'rule by bureaucracy' in Russia was bringing in class distinctions there, he told me 'if anything could destroy my sympathy with the Russian regime, it would be the growth of class distinctions" . Furthermore, Ray Monk cites Wittgenstein's friend, George Thomson as saying that Wittgenstein's attitude towards Marxism was that "[h]e was opposed to it in theory but supported it in practice" and Monk notes that "[t]his chimes with a remark Wittgenstein made to Rowland Hutt...: 'I am a communist, at heart". Monk concludes that "[t]here is no doubt that during the political upheavals of the mid-1930s Wittgenstein's sympathies were with the working class and the unemployed, and that his allegiance, broadly speaking, was with the Left"[40].

So it seems that Wittgenstein's interest in Russia did have something to do with political and social matters. Wittgenstein admired the Russian regime for providing full-employment and for eradicating class distinctions (as he saw it). Wittgenstein, despite having some serious reservations, had some respect for Marxist theory, and this can be seen in the fact that he used the formulation "the transition "from quantity to quality"'[41] in $\$ 284$ of the Philosophical Investigations which is drawn ultimately from Hegel but which later appeared as Engels' 'first law' of dialectics. And there is new evidence from Rush Rhees' notes of conversations with Wittgenstein, published in Mind recently, that Wittgenstein was thinking of Marxist ideas in this passage. According to Rhees, "Marx got the phrase from Hegel but I think Wittgenstein had Marxist ideas in mind here"[42]. This is not to suggest that Wittgenstein was a full-blown communist but it does at least indicate that Wittgenstein was not conservative in all of his political views. Wittgenstein was deeply conservative in his attitudes towards women but this did not form part of a wider conservative outlook when Wittgenstein was working on his later philosophy.

\section{IV - Wittgenstein's Philosophy}

\section{(i) Nyiri on Wittgenstein and Grillparzer}

In this section I will pick up on the second of the questions I raised in the introduction: do Wittgenstein's philosophical remarks have conservative implications? I will start by looking at Nyiri's arguments concerning Wittgenstein and the conservative poet Franz Grillparzer and then move on to look at the remarks in On Certainty mentioned by Nyiri.

Nyiri proposed that Wittgenstein's admiration for Grillparzer and his own family's connections with Grillparzer were good evidence that Wittgenstein was conservative. It should be clear, first of all, that a family connection and a remark from Wittgenstein about the good Austrian work of Grillparzer (amongst others) do not constitute solid evidence that Wittgenstein was conservative. Your grandmother's acquaintances do not all necessarily hold the same politics as you do and it is possible to have admiration for a poet's work without agreeing with their politics. The second remark from Wittgenstein about Grillparzer was a quote from Grillparzer and we should ask whether it is a case of Wittgenstein highlighting something that he saw as good in Grillparzer's conservatism. However, it is far from clear that this was Wittgenstein's intention. The passage in question was: "How easy it is to move about in broad distant regions, how hard it is to grasp what is individual and near at hand". Nyiri defended this as an expression of conservative politics by arguing that Wittgenstein was here contrasting concrete uses 
of language and speculative chatter. Conservatives, according to Nyiri, favour concrete uses of language ("individual and near") over speculative chatter ("broad distant regions") because they doubt that theorising about society is worthwhile, or even whether it is possible. But there are clear suggestions elsewhere in Wittgenstein's work that the contrast between concrete uses and speculative chatter is not what he had in mind. In the Philosophical Investigations, Wittgenstein looks to the correct use of ordinary terms in contrast to the misuse of terms by earlier philosophers. The contrast that Wittgenstein has in mind in the Investigations is the contrast between sense and nonsense. So, for example, at $\$ 39$ Wittgenstein picks apart referentialist 'theories' of meaning by arguing that

...it is clear that the sentence 'Nothung has a sharp blade' has a sense whether Nothung is still whole or has already been shattered. But if 'Nothung' is the name of an object, this object no longer exists when Nothung is shattered into pieces; and as no object would then correspond to the name, it would have no meaning. But then the sentence 'Nothung has a sharp blade' would contain a word that has no meaning, and hence the sentence would be nonsense. But it does have a sense...

Wittgenstein makes a similar point when he argues that " $[\mathrm{w}]$ hen $\mathrm{Mr}$ N. N. dies, one says that the bearer of the name dies, not that the meaning dies. And it would be nonsensical to say this, for if the name ceased to have meaning, it would make no sense to say ' $\mathrm{Mr}$ N. N. is dead"' (PI §40). Later on in the Investigations Wittgenstein clearly connects the tasks of philosophy with this distinction between sense and nonsense when he says that "[t]he results of philosophy are the discovery of some piece of plain nonsense and the bumps that the understanding has got by running up against the limits of language" (PI $\S 119)$. Seen in this light it seems plausible that Wittgenstein was not contrasting 'concrete' uses of language with speculative chatter about how to organize society, as Nyiri argues, rather he was contrasting broad attempts to grasp the essence of language or some other phenomenon (which lead us into speaking nonsense) and particular, correct, ordinary uses of language (which make sense). His discussion of the nature of philosophy in the Philosophical Investigations suggests that Wittgenstein wanted to look closely at particular uses of language in order to dissolve philosophical problems that arise "when language goes on holiday", i.e. when people do not use words correctly and end up speaking nonsense. So it is far from obvious that the passage from Grillparzer supports the view that Wittgenstein was a conservative. When Wittgenstein talks about that which is "individual and near" it seems plausible that he is talking about looking at particular, correct, ordinary uses of language in contrast to the "broad distant regions" of metaphysical nonsense.

The final passage in Wittgenstein's notebooks where he mentions Grillparzer is the one where he contrasts the 'nordic' face of Grillparzer with the 'alpine' face of Bruckner and Schubert. Nyiri tries to suggest that this passage is indicative of conservatism because it represents a kind of emphasis on diversity that conservatives favour. However, even if Wittgenstein's intention is to highlight diversity, it is unclear that an emphasis on diversity of any and every sort is characteristic of conservatism. For example, the conservative chancellor of Germany, Angela Merkel, has made a point of saying that having diverse cultures within a country does not work. At a meeting in Potsdam in 2010 she said that "[t]his [multicultural] approach has failed, utterly failed"[43] . David 
Cameron, the conservative Prime Minister of Great Britain, made the same point in 2011 at a conference in Munich soon after [44]. This may not be the kind of diversity (cultural diversity) that Nyiri had in mind but if he does not have this kind of emphasis on diversity in mind it seems a little implausible that we are to look for the diversity favoured by conservatives in the particular instances mentioned by Wittgenstein (i.e. 'faces', musical styles, kinds of poetry)[45]. And even if we were to accept that the passage about Bruckner was suggestive of conservatism in Wittgenstein's political views it would not demonstrate that Wittgenstein's philosophy is conservative.

Nyiri argues that the third passage in Wittgenstein's notebooks about Grillparzer (about his 'nordic' face) is to be understood in the light of the comment Wittgenstein makes afterwards. This is where Wittgenstein talks about " $[\mathrm{t}]$ he power of language to make everything look the same... which makes it possible to personify time, something which is no less remarkable than would have been making divinities of the logical constants". Rather than interpreting this, as Nyiri does, as representing a conservative stress on diversity, it would perhaps be more natural to interpret it again in the light of Wittgenstein's remarks about the nature of philosophy, sense, and nonsense. Given that Wittgenstein makes mention of the 'divinity' of the logical constants here it would make sense to interpret this as a remark which has his predecessors in the philosophy of logic in mind. When Wittgenstein was writing his later philosophy he often attacked the referentialism and philosophy of logic associated with Gottlob Frege and Bertrand Russell. The natural way to interpret the comment would be as an attack on their philosophy which, as Wittgenstein saw it, obscured the understanding of language by assimilating expressions to one another[46] and which made the mistake of thinking that the logical constants must refer to entities (a view which he attacked in both his early and his later work). The point is that it is more natural to understand Wittgenstein as making a philosophical point here (i.e. as one to do with language, logic, sense, and nonsense) rather than as making a political point about the superiority of conservatism over its left-wing or liberal rivals. Indeed, in The Blue Book Wittgenstein says something similar to the passage quoted by Nyiri in the context of discussing conceptual confusions surrounding the notion of 'time'. There he says that, "[i]f we look into the grammar of that word, we shall feel that it is no less astounding that man should have conceived a deity of time than it would be to conceive of a deity of negation or disjunction."[47]

Similarly, it is more natural to understand Wittgenstein as making philosophical points (which are consistent with any political ideology) in the remarks that Nyiri cites from On Certainty than it is to understand them as in some way expressing sympathy for conservative political views. For example, Nyiri cites $\S 47$ from On Certainty in support of his argument because it mentions school as an authority. What Wittgenstein actually says is, "[t]his is how one calculates. Calculating is this. What we learn at school, for example. Forget this transcendent certainty which is connected with your concept of spirit". The context for this remark is a discussion of the concepts of 'knowledge', 'doubt', 'certainty', and 'belief'. Wittgenstein has moved on from discussing Moore's claims to know things like 'here is a hand' and is discussing knowledge and certainty in the area of mathematics. An earlier passage sheds some light on what is going on in $\S 47$ :

Knowledge in mathematics: Here one has to keep on reminding oneself of the unimportance of the 'inner process' or 'state' and ask "Why should it be 
important? What does it matter to me?" What is interesting is how we use mathematical propositions. (OC §38)

So the context is one in which Wittgenstein is arguing that we should move away from thinking about knowledge as an inner state (this is conceptually confused, as Wittgenstein argues elsewhere[48]) towards looking at how we actually use mathematical propositions. In $\S 47$ he is recommending that we move away from the conception of certainty that is associated with confused views of the mind (e.g. the view that knowledge is a mental state) and look at how mathematical propositions are learnt and used in practice. Wittgenstein is talking about how the concepts of 'calculating' and 'certainty' are employed. He makes no comment in $\$ 47$ about whether the ability to calculate must be acquired in a school - school is not seen as a necessary institution but as an instructive example - and nor does he make any comment on whether schools should be preserved as an institution or on whether, say, schoolchildren should respect school authorities. No conservative political point is made. The passage is part of an extended discussion which is intended to make our use of various related concepts ('calculate', 'knowledge', 'certainty', 'doubt', 'belief' and so on) more perspicuous with the aim of dissolving epistemological problems (for example, scepticism is compared to the "hypothesis of our having miscalculated in all our calculations"[49] - with the purpose of showing that neither is a possible hypothesis). Wittgenstein does, in a way, suggest that we should respect an authority. What we should respect is the correct uses of these terms. We should respect the correct uses of these terms if we do not want to be led astray into talking nonsense and get caught up in philosophical confusion. This is quite different to the conservative emphasis on respecting authorities such as the church, political authorities, and school teachers, which Wittgenstein makes no comment on.

\section{V-Conclusion}

So I conclude that none of the philosophical remarks in Wittgenstein's work discussed by Nyiri in his article endorse or imply a conservative viewpoint. Wittgenstein's philosophy concerns confusions about concepts rather than grappling with ideological problems either directly or indirectly. There is some evidence that Wittgenstein was conservative, at least in some respects, in his politics, but his philosophical work does not have any obvious political implications. I leave open the possibility that it might nonetheless have non-obvious political implications. My principal concern here has been to demonstrate that some of the arguments offered in favour of Wittgenstein being conservative, by the likes of Nyiri, miss their mark[50].

[1] Perhaps most famously, J.C. Nyiri argued in a series of papers that Wittgenstein was a conservative philosopher (see, for example, 'Wittgenstein 1929-31: The Turning Back' in Ludwig Wittgenstein: Critical Assessments (Vol. 4), edited by Stuart Shanker, London: Routledge, 1986). Those agreeing with Nyiri in this include Perry Anderson, Alex Callinicos, and H. C. McCauley. Those arguing that Wittgenstein's philosophy was not conservative include Joachim Schulte ('Wittgenstein and Conservatism', in Ludwig Wittgenstein: Critical Assessments (Vol. 4), edited by Stuart Shanker, London: Routledge, 1986), Andrew Lugg (in 'Wittgenstein and Politics: Not Right, Left or Center', International Studies in Philosophy, 36:1, 2004 and other papers), and see also Vinten, R. 'Leave Everything As It Is: A Critique of Marxist Interpretations of Wittgenstein', Critique, 41:1, 2013 and 'Eagleton's Wittgenstein', Critique, Vol.43, 2015 . This is just a small selection of all that has been written on the subject. 
Revista Estudos Hum(e)anos

ISSN 2177-1006

Número 8, 2014/1

[2] Quinton, A. 'Conservatism' in A Companion to Contemporary Political Philosophy, (2 ${ }^{\text {nd }}$ edition, edited by Robert E. Goodin, Philip Pettit, and Thomas W. Pogge), Oxford, Blackwell, 2009, p. 285

[3] Hayek, F. A. The Constitution of Liberty, Chicago: The University of Chicago Press, 1960

[4] See Quinton, A. 'Conservatism' in A Companion to Contemporary Political Philosophy, $\left(2^{\text {nd }}\right.$ edition, edited by Robert E. Goodin, Philip Pettit, and Thomas W. Pogge), Oxford, Blackwell, 2009, p.296

[5] Quinton, A. 'Conservatism' in A Companion to Contemporary Political Philosophy, (2nd edition, edited by Robert E. Goodin, Philip Pettit, and Thomas W. Pogge), Oxford: Blackwell, 2009, pp.285-6

[6] Epstein, K. The Genesis of German Conservatism, Princeton, NJ: Princeton University Press, 1966 cited in Nyiri, 'The Turning Back', p.37

[7] Nash, G. The Conservative Intellectual Movement in America Since 1945, p.xiv

[8] Robin, C. The Reactionary Mind: Conservatism from Edmund Burke to Sarah Palin, Oxford: Oxford University Press, 2011, p.4

[9] Cited in Robin, C. The Reactionary Mind: Conservatism from Edmund Burke to Sarah Palin, Oxford: Oxford University Press, 2011, p.19

[10] Robin, C. The Reactionary Mind: Conservatism from Edmund Burke to Sarah Palin, Oxford: Oxford University Press, 2011, p.16

[11] Pinsent, D. in A Portrait of Wittgenstein as a Young Man: From the Diary of David Hume Pinsent 1912-1914, edited by G. H. Von Wright, Oxford: Blackwell, 1990, p.44. Perhaps some would question whether conservatism should be associated with sexism such as this. The reason for doing so is that conservatives revere existing political institutions and oppose radical change. At the time in Britain women did not have the vote and granting them the vote was a radical change.

[12] Pascal, F. 'A Personal Memoir' in Recollections of Wittgenstein (Revised edition), edited by Rush Rhees, Oxford: OUP, 1984, p.17

[13] Dyson, F. interview on 'Web of Stories' website

http://www.webofstories.com/play/freeman.dyson/47;jsessionid=27BB84B2E9D0A7D1F0C0C 403063703B9 accessed 15/12/14.

[14] Pascal, F. 'A Personal Memoir' in Recollections of Wittgenstein (Revised edition), edited by Rush Rhees, Oxford: OUP, 1984, p.17

[15] Monk, R. Ludwig Wittgenstein: The Duty of Genius, London: Vintage, 1991, p.336. Of course, none of this demonstrates that Wittgenstein was not sexist.

[16] Monk, R. Ludwig Wittgenstein: The Duty of Genius, London: Vintage, 1991, p.498. Another reason to doubt Dyson's claims is that Dyson did not know Wittgenstein well at all and was a physicist rather than a philosopher. Dyson had limited interaction with Wittgenstein.

[17] Rhees said this in letters to John Moran which Moran cites in his article 'Wittgenstein and Russia', New Left Review, I/73, 1972

[18] Drury, M. O'C. 'Conversations with Wittgenstein' in Recollections of Wittgenstein, edited by Rush Rhees, Oxford: OUP, 1984, p.126

[19] Nyiri, J. C. 'Wittgenstein 1929-31: The Turning Back' in Ludwig Wittgenstein: Critical Assessments, edited by Stuart Shanker, London: Routledge, 1986

[20] Nyiri, J. C. 'Wittgenstein 1929-31: The Turning Back' in Ludwig Wittgenstein: Critical Assessments, edited by Stuart Shanker, London: Routledge, 1986, p.40 
Revista Estudos Hum(e)anos

ISSN 2177-1006

Número 8, 2014/1

[21] From an entry in Wittgenstein's notebooks on $7^{\text {th }}$ November 1929, cited on p41 of Nyiri, J. C. 'Wittgenstein 1929-31: The Turning Back' in Ludwig Wittgenstein: Critical Assessments, edited by Stuart Shanker, London: Routledge, 1986. This is Nyiri's translation. In Culture and Value it is translated as "I think good Austrian work (Grillparzer, Lenau, Bruckner, Labor) is particularly hard to understand " (my italics)

[22] This remark has been published in Wittgenstein, L. Culture and Value, Oxford: Blackwell. Nyiri cites the passage on page 42 of 'Wittgenstein 1929-31: The Turning Back' in Ludwig Wittgenstein: Critical Assessments, edited by Stuart Shanker, London: Routledge, 1986.

[23] Nyiri, J. C. 'The Turning Back', p.42

[24] Nyiri, J. C. 'The Turning Back', p.38

[25] Nyiri's discussion of the passage in question appears on p.41 of 'The Turning Back'.

[26] The quote comes from Epstein, K. The Genesis of German Conservatism, cited in Nyiri, J. C., 'The Turning Back', p.37.

[27] Note here that this is Nyiri's rendering of OC, $\S 493$. Wittgenstein in fact puts $\S 493$ in the form of a question: "So is this it: I must recognise certain authorities in order to make judgements at all?" (in On Certainty, New York: Harper Row, 1972 (originally published by Basil Blackwell, 1969))

[28] Nyiri, J.C., 'The Turning Back', p.40. The passages from Wittgenstein he mentions are "This is how one calculates. Calculating is this. What we learn at school, for example. Forget this transcendent certainty, which is connected with your concept of spirit."(OC, §47), "For otherwise, wouldn't all assertion be discredited in this way?" (OC, §644) and "But I did not get my picture of the world by satisfying myself of its correctness; nor do I have it because I am satisfied of its correctness. No: it is the inherited background against which I distinguish between true and false" (OC, §94)

[29] See, for example, Ray Monk's biography of Ludwig Wittgenstein (Ludwig Wittgenstein: The Duty of Genius, London: Vintage, 1991), F. A. Flowers Portraits of Wittgenstein, Thoemmes Continuum, 1999, and Vinten, R. 'Leave Everything As It Is: A Critique of Marxist Interpretations of Wittgenstein', in Critique, 41:1, pp.9-22

[30] Pascal, F. 'A Personal Memoir' in Recollections of Wittgenstein, ed. Rush Rhees, Oxford: OUP, 1984 (Revised edition), p. 14

[31] Wittgenstein, L. Philosophical Investigations (Preface), p. 4 (in the Revised $4^{\text {th }}$ edition by P.M.S. Hacker and Joachim Schulte, Oxford: Wiley-Blackwell, 2009

[32] See Monk, R. Ludwig Wittgenstein: The Duty of Genius, London: Vintage, 1991, p.272, p.343, and p.347

[33] Drury, M. O'C. 'Conversations with Wittgenstein' in Recollections of Wittgenstein, edited by Rush Rhees, Oxford: OUP, 1984, p.126

[34] In a letter to John Moran "Rhees twice emphasized that Wittgenstein regarded not Marx's views, but 'the way he wrote'... as infuriating". See Moran, J. 'Wittgenstein and Russia', in New Left Review, I/73, May-June, 1972

[35] In a letter to Paul Engelmann. See Engelmann, P. Letters From Ludwig Wittgenstein. With a Memoir, translated by L. Fürtmüller, edited by Brian McGuinness, Oxford: Blackwell, 1967, pp.52-53

[36] Pascal, F. 'A Personal Memoir' in Recollections of Wittgenstein, ed. Rush Rhees, Oxford: OUP, 1984 (Revised edition), p.29 
Revista Estudos Hum(e)anos

ISSN 2177-1006

Número 8, 2014/1

[37] Pascal, F. 'A Personal Memoir' in Recollections of Wittgenstein, ed. Rush Rhees, Oxford: OUP, 1984 (Revised edition), pp.44-5. J.C. Nyiri associates Wittgenstein's interest in Russia with conservatism in 'The Turning Back', pp.45-6.

[38] See Monk, R. Ludwig Wittgenstein: The Duty of Genius, p.349

[39] Rhees, R. 'Postscript' in Recollections of Wittgenstein, edited by Rush Rhees, 1984, p.205

[40] Monk, R., Ludwig Wittgenstein: The Duty of Genius, London: Vintage, 1991, p.343

[41] Wittgenstein, L. Philosophical Investigations, §284

[42] Citron, G., Rhees, R., and Wittgenstein, L. 'Wittgenstein's Philosophical Conversations with Rush Rhees (1939-50): From the Notes of Rush Rhees, Mind, Vol.124 : 493, January 2015

[43] Quote taken from 'Angela Merkel: German multiculturalism has "utterly failed' in the Guardian newspaper, 17/10/2010, http://www.theguardian.com/world/2010/oct/17/angela-merkel-german-multiculturalism-failed, accessed 19/12/2014

[44] See 'PM's speech at Munich Security Conference' https://www.gov.uk/government/speeches/pms-speech-at-munich-security-conference, 05/02/2011, accessed 19/12/2014

[45] A similar point can be made about Nyiri's suggestion that conservatives place particular emphasis on particularity - on concrete circumstances. From the opposite end of the political spectrum Vladimir Lenin argued that "[t]he Marxist dialectic demands a concrete analysis of each specific historical situation" (in The Junius Pamphlet (1916) in CW 22:316 - where he stressed the importance of knowledge of detail rather than a priori reasoning). This suggests that an emphasis on the concrete is not distinctive of conservatism.

[46] So, for example, in $\S 10$ of the Investigations Wittgenstein says “....making the description of the uses of these words [number words, object words, and so on] similar in this way [saying that they all signify something] cannot make the uses themselves any more like one another!" and in $\S 11$ he suggests that it would be better to think of words by analogy with tools, with various uses/functions.

[47] Wittgenstein, L. The Blue and Brown Books, Harper and Row: New York, 1958, p.6. Wittgenstein also comments on conceptual confusions about time in the Philosophical Investigations, see, for example, $\S 90, \S 196$

[48] See §§148-155 Philosophical Investigations

[49] Wittgenstein, L. On Certainty, New York: Harper \& Row, 1972, §55

[50] I am grateful to the Fundação para a Ciência e a Tecnologia for funding while I have been working on this paper. 